\title{
Pengaruh Takaran Arang Sekam Padi dan Frekuensi Penyemprotan Pupuk Organik Cair Terhadap Pertumbuhan dan Hasil Tanaman Cabe Merah (Capsicum annum, L.)
}

\section{Yuven Lolomsait a}

${ }^{a}$ Fakultas Pertanian, Universitas Timor, Kefamenanu, TTU - NTT, Indonesia.

\section{Article Info}

\section{Article history:}

Received 12 Maret 2016

Received in revised form 28 Juni 2016

Arang Sekam Padi

Frekuensi Penyemprotan POC

Cabe Merah

Capsicum annum, $\mathrm{L}$
Accepted 24 September 2016

\begin{abstract}
Abstrak
Penelitian ini bertujuan mengetahui pengaruh takaran arang sekam dan frekuensi penyemprotan pupuk organik cair terhadap pertumbuhan dan hasil tanaman cabe merah. Penelitian mengunakan rancangan acak kelompok (RAK). Faktor pertama adalah takaran arang sekam, terdiri dari 3 level yaitu $1 \mathrm{~kg} /$ petak, $1,5 \mathrm{~kg} /$ petak dan $2 \mathrm{~kg} /$ petak. Faktor kedua adalah frekuensi penyemprotan yang terdiri dari 3 level, yakni 1 kali (15 HST), 2 kali (15 dan 30 HST dan 3 kali (15, 30, 45 HST). Hasil penelitian menunjukan bahwa interaksi antara takaran arang sekam padi dan frekuensi penyemprotan terjadi pada kadar lengas tanah $30 \mathrm{HST}$, tinggi tanaman $48 \mathrm{HST}$, dan diameter batang 48 HST. Takaran arang sekam padi berpengaruh nyata terhadap suhu tanah 30 dan 48 HST, kadar lengas tanah 30 HST, diameter batang 48 HST, dan panjang buah per tanaman. Sedangkan frekuensi penyemprotan berpengaruh nyata terhadap kadar lengas tanaman 48 HST, tinggi tanaman pada 48 HST. Takaran arang sekam padi $2 \mathrm{~kg}$ menghasilkan berangkasan segar dan berangkasan kering yang paling berat. Frekuensi penyemprotan tiga kali memberikan hasil panen per tanaman berupa buah yang paling panjang dan yang paling banyak. (O2016 dipublikasikan oleh Savana Cendana.
\end{abstract}

\section{Pendahuluan}

Cabai merah (Capsicum annum, L.) adalah sayuran buah semusim yang termasuk dalam anggota genus Capsicum yang banyak diperlukan oleh masyarakat sebagai penyedap rasa masakan (Sunaryono, 2003). Salah satu tanaman cabai yang banyak dibudidayakan di Indonesia adalah tanaman cabai merah. Cabai merah merupakan komoditas sayuran yang banyak digemari oleh masyarakat. Ciri dari jenis sayuran ini adalah rasanya yang pedas dan aromanya yang khas, sehingga bagi orang-orang tertentu dapat membangkitkan selera makan. Karena merupakan sayuran yang dikonsumsi setiap saat, maka cabai akan terus dibutuhkan dengan jumlah yang semakin meningkat seiring dengan pertumbuhan jumlah penduduk dan perekonomian nasional (Rukmana, 2002).

Cabai merah mengandung berbagai macam senyawa yang berguna bagi kesehatan manusia. Kandungan vitamin dalam cabai adalah A dan $\mathrm{C}$ serta mengandung minyak atsiri, yang rasanya pedas dan memberikan kehangatan bila kita gunakan untuk rempah - rempah (bumbu- bumbu dapur) (Darmayati, 2003). Kandungan gizi pada tanaman cabai merah meliputi: energy 31 kalori, protein $1,0 \mathrm{~g}$, lemak $0,3 \mathrm{~g}$, karbohidrat $7,9 \mathrm{~g}$, kalsium $29 \mathrm{~g}$, fosfor $24 \mathrm{~g}$, vitmin A $470 \mathrm{SI}$ vitamin C $181 \mathrm{mg}$

Produksi cabai besar di Kabupaten Timor Tengah Utara (TTU) dari tahun 2007-2010 adalah 95 ton, 30 ton, dan 30 ton (BPS, 2010), dan penurunan produksi cabai merah disebabkan oleh penggunaan pupuk anorganik. Hal in didasarkan pada kenyataan bahwa di wilayah Kabupaten Timor Tengah Utara masyarakat petani belum banyak menerapkan tentang penggunaan arang sekam dan frekuensi pupuk organik cair dalam budidaya cabai merah.

Budidaya cabai merah membutuhkan air untuk penyiramannya yang cukup. Penggunaan arang sekam dapat dimanfaatkan untuk menekan tingginya kebutuhan air penyiraman karena mempunyai karakteristik ringan sehingga sirkulasi udaranya tinggi, kapasitas menahan air tinggi, berwarna hitam sehingga dapat mengabsorbsi sinar matahari dengan baik. Rongganya banyak sehingga aerasi dan drainasenya baik, hal inis juga mempermudah pergerakan akar tanaman dalam media tanam tersebut. Arang sekam telah steril, karena saa pembuatannya sekam telah mendapat panas yang tinggi karena proses pembakaran sehingga tidak memerlukan desinfeksi denagn kemikalia apapun. Mempunyai daya melapuk lambat dan dianggap dapat bertahan kira - kira satu tahun sehingga dapat digunakan beberapa kali (Wuryaningsih, 2008).

Kebiasaan petani dalam membudidayakan cabai merah besar belum menggunakan arang sekam dan pada umumnya masyarakat belum mengenal apa itu arang sekam, petani pada umumnya menanam cabai hanya menggunakan bahan kimia.

Arang sekam dapat terdekomposisi menjadi bahan organik oleh karenanya dapat pula meningkatkan ketersediaan unsur hara di dalam tanah. Namun kebutuhan hara yang cukup membutuhkan pemupukan yang aplikasinya lebih efisien bila melalui daun

Dalam budidaya cabai besar sebagian petani belum menggunakan pupuk, ada yang sebagian kecil sudah menggunakan pupuk organik cair namun dalam penyemprotannya petani tidak menggunakan takaran.

Manfaat penyemprotan pupuk organik cair melalui daun antara lain (Ayub S. dan Pranata. 2004):

a) Dapat mendorong dan meningkatkan pembentukan klorofil daun dan pembentukan bintil akar pada tanaman leguminose sehingga meningkatkan kemampuan fotosintesis tanaman dan penyerapan nitrogen dari udara.

b) Dapat meningkatkan vigor tanaman sehingga tanaman menjadi kokoh dan kuat, meningkatkan daya tahan tanaman terhadap kekeringan, cekaman cuaca dan serangan patogen penyebab penyakit.

c) Merangsang pertumbuhan cabang produksi.

d) Meningkatkan pembentukan bunga dan bakal buah

e) Mengurangi gugurnya daun, bunga dan bakal buah.

Penggunaan arang sekam pada media tanam dan pupuk organik cair melalui daun belum banyak dilakukan oleh petani. Selain itu, informasi mengenai arang sekam dan pupuk organik cair pada tanaman cabai serta pengaruhnya terhadap pertumbuhan cabai di masyarakat sangat terbatas. Oleh karenanya perlu melakukan penelitian tentang "Pengaruh Takaran Arang Sekam dan Frekuensi Pupuk Organik Cair Terhadap Pertumbuhan dan Hasil Tanaman Cabai Merah.

\section{Metode}

Penelitian telah dilaksanakan pada Desember 2015 sampai Februari 2016 di Desa Haulasi, Kecamatan Miomaffo Barat, Kabupaten TTU. Rancangan yang digunakan dalam penelitian ini adalah Rancangan Acak Kelompok (RAK) 3 x 3 yang diulang dalam 3 blok. Faktor pertama adalah takaran arang sekam (A) yang terdiri dari 3 perlakuan yaitu 0,5t/m (A1), 1,5 kg/petak (A2) dan $2 \mathrm{~kg} /$ petak (A3). Faktor kedua adalah frekuensi pupuk organik cair $(\mathrm{F})$ yang terdiri dari 3 perlakuan yaitu 1 kali pada $15 \mathrm{HST}$ (F1), 2 kali pada 15, $30 \mathrm{HST}$ (F2) dan 3 kal pada15, 30, 45 HST (F3).

Data hasil pengamatan kemudian dianalisis dengan menggunakan sidik ragam (Anova) Rancangan Acak Kelompok (RAK). Rata-rata perlakuan selanjutnya diuji lanjut dengan menggunakan DMRT (Duncan multiple range test) dengan tingkat signifikasi 5\% sesuai petunjuk Gomez dan Gomez, (1995). Analisis data menggunakan program SAS 9.1.

\section{Hasil dan Pembahasan \\ 3.1 Suhu Tanah}

Hasil sidik ragam (Anova) menunjukkan bahwa tidak terjadi interaksi antara takaran arang sekam padi dan frekuensi penyemprotan pupuk organic ai terhadap suhu tanah pada setiap pengamatan dimana suhu tanah pada petak yang diberikan arang sekam padi dengan takaran $1,5 \mathrm{~kg}$ per petak tanam yang disemprot setiap tiga kali memiliki hasil paling tinggi pada pengamatan 12 HST.

Tabel 1. Suhu Tanah $\left({ }^{\circ} \mathrm{C}\right)$

\begin{tabular}{cccccc}
\hline Waktu & Takaran & \multicolumn{2}{c}{ Frekuensi Penyemprotan POC } & \multirow{2}{*}{ Rerata } \\
\cline { 2 - 5 } Pengamatan & Arang Sekam & 1 kali & 2 kali & $3 \mathrm{kali}$ & \\
\hline \multirow{4}{*}{$12 \mathrm{HST}$} & $1 \mathrm{~kg}$ & 36.2 & 35.6 & 35.5 & $35.8 \mathrm{a}$ \\
& $1,5 \mathrm{~kg}$ & 36.5 & 36.8 & 37.1 & $36.8 \mathrm{a}$ \\
& $2 \mathrm{~kg}$ & 35.1 & 35.4 & 36.5 & $35.7 \mathrm{a}$ \\
\cline { 2 - 5 } & Rerata & $35.9 \mathrm{a}$ & $35.9 \mathrm{a}$ & $36.3 \mathrm{a}$ & $(-)$ \\
\hline \multirow{3}{*}{$30 \mathrm{HST}$} & $1 \mathrm{~kg}$ & 31.5 & 32.7 & 33.0 & $32.4 \mathrm{~b}$ \\
& $1,5 \mathrm{~kg}$ & 33.9 & 33.3 & 33.2 & $33.5 \mathrm{a}$ \\
& $2 \mathrm{~kg}$ & 33.5 & 34.3 & 34.7 & $34.2 \mathrm{a}$ \\
\cline { 2 - 5 } & Rerata & $33.0 \mathrm{a}$ & $33.4 \mathrm{a}$ & $33.6 \mathrm{a}$ & $(-)$ \\
\hline \multirow{3}{*}{$48 \mathrm{HST}$} & $1 \mathrm{~kg}$ & 30.9 & 32.4 & 32.8 & $32.1 \mathrm{~b}$ \\
& $1,5 \mathrm{~kg}$ & 33.7 & 33.3 & 33.4 & $33.5 \mathrm{a}$ \\
& $2 \mathrm{~kg}$ & 33.6 & 33.9 & 34.1 & $33.9 \mathrm{a}$ \\
\cline { 2 - 5 } & Rerata & $32.7 \mathrm{a}$ & $33.2 \mathrm{a}$ & $33.4 \mathrm{a}$ & $(-)$
\end{tabular}

Keterangan: Angka pada baris dan kolom yang diikuti dengan huruf yang sama tidak berbeda nyata menurut uji DMRT $\alpha 5 \%$. (-): Tidak terjadi interaksi antar faktor

Data pada Tabel 1. menunjukan bahwa pada 30 HST dan 48 HST dimana suhu tanah pada petak yang diberikan arang sekam padi dengan takaran $1,5 \mathrm{~kg}$ dan takaran $2 \mathrm{~kg}$ per petak tanam berbeda nyata dengan petak yang diberikan takaran $1 \mathrm{~kg}$ per lubang tanam dengan frekuensi penyemprotan tiga kali cendrung labih tinggi dibandingkan dengan takaran arang sekam dan frekuensi penyemprotan lainnya,

Frekuensi penyiraman tidak berpengaruh nyata terhadap suhu tanah setiap waktu pengamatan dimana suhu tanah pada petak yang disemprot tiga kali sekali selalu paling tinggi dari frekuensi penyemprotan lainnya.

\subsection{Kadar Lengas Tanah}

Hasil sidik ragam (Anova) menunjukkan bahwa terjadi interaksi antara takaran arang sekam padi dan frekuensi penyiraman terhadap kadar lengas tanah pada pengamatan 30 HST dimana kadar lengas tanah pada petak yang diberikan 
arang sekam padi dengan takaran $1 \mathrm{~kg}$ per petak tanam yang disemprot dua kali paling tinggi.

Pada pengamatan 12 HST takaran arang sekam dan frekuensi penyemprotan tidak berbeda nyata dimana kadar lengas tanah pada petak yang diberikan arang sekam padi dengan takaran $1,5 \mathrm{~kg}$ per petak tanam kemudian disemprot tiga kali memberikan paling tinggi.

Takaran arang sekam padi tidak berbeda nyata terhadap kadar lengas tanah 48 HST tetapi data Tabel 2. menunjukkan bahwa kadar lengas tanah pada petak yang diberikan arang sekam padi dengan takaran $2 \mathrm{~kg}$ per petak tanam cenderung lebih tinggi.

Tabel 2. Kadar Lengas Tanah (\%)

\begin{tabular}{cccccc}
\hline Waktu & Takaran & \multicolumn{2}{l}{ Frekuensi Penyemprotan POC } & \multirow{2}{*}{ Rerata } \\
\cline { 2 - 5 } Pengamatan & Arang Sekam & $1 \mathrm{kali}$ & $2 \mathrm{kali}$ & $3 \mathrm{kali}$ & \\
\hline \multirow{3}{*}{$12 \mathrm{HST}$} & $1 \mathrm{~kg}$ & 16.4 & 12.9 & 22.1 & $17.1 \mathrm{a}$ \\
& $1,5 \mathrm{~kg}$ & 11.0 & 25.8 & 21.1 & $19.3 \mathrm{a}$ \\
& $2 \mathrm{~kg}$ & 11.7 & 13.7 & 12.3 & $12.6 \mathrm{a}$ \\
\cline { 2 - 5 } & Rerata & $13.0 \mathrm{a}$ & $17.5 \mathrm{a}$ & $18.5 \mathrm{a}$ & $(-)$ \\
\hline \multirow{3}{*}{$30 \mathrm{HST}$} & $1 \mathrm{~kg}$ & $25.4 \mathrm{a}$ & $22.8 \mathrm{ab}$ & $18.5 \mathrm{abc}$ & $22.3 \mathrm{a}$ \\
& $1,5 \mathrm{~kg}$ & $18.1 \mathrm{abc}$ & $9.6 \mathrm{~d}$ & $13.6 \mathrm{~cd}$ & $13.7 \mathrm{~b}$ \\
& $2 \mathrm{~kg}$ & $7.7 \mathrm{~d}$ & $15.1 \mathrm{bcd}$ & $10.7 \mathrm{~cd}$ & $11.2 \mathrm{~b}$ \\
\cline { 2 - 5 } & Rerata & $17.1 \mathrm{a}$ & $15.8 \mathrm{a}$ & $14.3 \mathrm{a}$ & $(+)$ \\
\hline \multirow{3}{*}{$48 \mathrm{HST}$} & $1 \mathrm{~kg}$ & 19.7 & 20.4 & 12.3 & $17.5 \mathrm{a}$ \\
& $1,5 \mathrm{~kg}$ & 13.9 & 8.0 & 14.2 & $12.0 \mathrm{a}$ \\
& $2 \mathrm{~kg}$ & 26.3 & 13.2 & 13.9 & $17.8 \mathrm{a}$ \\
\cline { 2 - 5 } & Rerata & $19.9 \mathrm{a}$ & $13.9 \mathrm{~b}$ & $13.5 \mathrm{~b}$ & $(-)$ \\
\hline
\end{tabular}

Keterangan: $\quad$ Angka pada baris dan kolom yang diikuti dengan huruf yang sama tidak berbeda nyata menurut uji DMRT $\alpha 5 \%$. (-): Tidak terjadi interaksi antar faktor

Frekuensi penyiraman tidak nyata berpengaruh terhadap kadar lengas tanah saat pengamatan 12 HST dan 30 HST tetapi data Tabel 2. menunjukkan bahwa kadar lengas tanah pada petak yang disiram setiap tiga hari cenderung lebih tinggi pada pengamatan 12 HST, sedangkan pada pengamatan $30 \mathrm{HST}$ petak yang disemprot 2 kali memiliki hasil tertinggi. Saat pengamatan $48 \mathrm{HST}$, frekuensi penyemprotan berpengaruh nyata terhadap kadar lengas tanah dimana kadar lengas tanah pada petak yang disemprot satu kali paling tinggi dan berbeda nyata dengan kadar lengas tanah pada petak yang disemprot dua kali tetapi tidak berbeda nyata dengan kadar lengas tanah pada petak yang disemprot tiga kali.

\subsection{Berat Volume Tanah}

Hasil sidik ragam (Anova) menunjukkan bahwa tidak terjadi interaksi antara takaran arang sekam padi dan frekuensi penyiraman terhadap berat volume tanah setiap waktu pengamatan. tetapi data pada Tabel 3. menunjukkan bahwa pada setiap waktu pengamatan, tanaman yang diberikan arang sekam padi $2 \mathrm{~kg}$ per petak tanam selalu cenderung lebih tinggi.

Frekuensi penyiraman tidak berbeda nyata terhadap berat volume tanah setiap waktu pengamatan dimana tanaman yang disiram setiap tiga kali paling tinggi.

Table 3. Berat Volume Tanah

\begin{tabular}{cccccc}
\hline Waktu & Takaran & \multicolumn{3}{c}{ Frekuensi Penyiraman } & \multirow{2}{*}{ Rerata } \\
\cline { 2 - 4 } Pengamatan & Arang Sekam & $1 \mathrm{kali}$ & $2 \mathrm{kali}$ & $3 \mathrm{kali}$ & \\
\hline \multirow{3}{*}{$12 \mathrm{HST}$} & $1 \mathrm{~kg}$ & 1.3 & 1.3 & 1.6 & $1.4 \mathrm{a}$ \\
& $1,5 \mathrm{~kg}$ & 1.5 & 1.3 & 1.5 & $1.4 \mathrm{a}$ \\
& $2 \mathrm{~kg}$ & 1.4 & 1.4 & 1.4 & $1.4 \mathrm{a}$ \\
\cline { 2 - 5 } & Rerata & $1.4 \mathrm{a}$ & $1.4 \mathrm{a}$ & $1.5 \mathrm{a}$ & $(-)$ \\
\hline \multirow{3}{*}{$30 \mathrm{HST}$} & $1 \mathrm{~kg}$ & 1.7 & 1.7 & 1.6 & $1.6 \mathrm{a}$ \\
& $1,5 \mathrm{~kg}$ & 1.5 & 1.7 & 1.6 & $1.6 \mathrm{a}$ \\
& $2 \mathrm{~kg}$ & 1.7 & 1.6 & 1.7 & $1.7 \mathrm{a}$ \\
\cline { 2 - 5 } & Rerata & $1.7 \mathrm{a}$ & $1.7 \mathrm{a}$ & $1.6 \mathrm{a}$ & $(-)$ \\
\hline \multirow{3}{*}{$48 \mathrm{HST}$} & $1 \mathrm{~kg}$ & 1.9 & 1.7 & 2.0 & $1.8 \mathrm{a}$ \\
& $1,5 \mathrm{~kg}$ & 1.7 & 2.0 & 1.7 & $1.8 \mathrm{a}$ \\
& $2 \mathrm{~kg}$ & 2.1 & 1.7 & 1.9 & $1.9 \mathrm{a}$ \\
\hline & Rerata & $1.9 \mathrm{a}$ & $1.8 \mathrm{a}$ & $1.9 \mathrm{a}$ & $(-)$
\end{tabular}

Keterangan: Angka pada baris dan kolom yang diikuti dengan huruf yang sama tidak berbeda nyata menurut uji DMRT $\alpha 5 \%$. (-): Tidak terjadi interaksi antar faktor

\subsection{Tinggi Tanaman}

Hasil sidik ragam (Anova) menunjukkan bahwa terjadi interaksi antara takaran arang sekam padi dan frekuensi penyiraman terhadap tinggi tanaman pada pengamatan 48 HST dimana kadar lengas tanah pada petak yang diberikan arang sekam padi dengan takaran $1 \mathrm{~kg}$ per petak tanam yang disemprot satu kali paling tinggi dan berbeda nyata dengan frekuensi penyemprotan 2 kali dan 3 kali. Takaran arang sekam padi juga tidak berpengaruh nyata terhadap tinggi tanaman pada pengamatan 12 HST dan 30 HST tetapi data pada Tabel 4. menunjukkan bahwa tanaman yang diberikan arang sekam padi $2 \mathrm{~kg}$ dan $1,5 \mathrm{~kg}$ per petak tanam selalu cenderung lebih tinggi dibandingkan dengan petak yang diberian arang sekam $1 \mathrm{~kg}$ per petak tanam.
Pada pengamatan 12 HST dan 30 HST Frekuensi penyemprotan tidak berpengaruh nyata terhadap tinggi tanaman, tetapi pertumbuhan tanaman selalu meningkat pada setiap pengamatan.

$\underline{\text { Tabel 4. Tinggi Tanaman }(\mathrm{cm})}$

\begin{tabular}{cccccc}
\hline Waktu & Takaran & \multicolumn{3}{c}{ Frekuensi Penyiraman } & \multirow{2}{*}{ Rerata } \\
\cline { 2 - 5 } Pengamatan & Arang Sekam & $1 \mathrm{kali}$ & $2 \mathrm{kali}$ & $3 \mathrm{kali}$ & \\
\hline \multirow{3}{*}{$12 \mathrm{HST}$} & $1 \mathrm{~kg}$ & 8.3 & 8.9 & 10.0 & $9.1 \mathrm{a}$ \\
& $1,5 \mathrm{~kg}$ & 7.2 & 9.2 & 8.9 & $8.5 \mathrm{a}$ \\
& $2 \mathrm{~kg}$ & 9.3 & 10.4 & 9.9 & $9.9 \mathrm{a}$ \\
\cline { 2 - 5 } & Rerata & $8.3 \mathrm{a}$ & $9.5 \mathrm{a}$ & $9.6 \mathrm{a}$ & $(-)$ \\
\hline \multirow{3}{*}{$30 \mathrm{HST}$} & $1 \mathrm{~kg}$ & 15.5 & 12.3 & 13.1 & $13.6 \mathrm{a}$ \\
& $1,5 \mathrm{~kg}$ & 15.4 & 13.6 & 12.3 & $13.8 \mathrm{a}$ \\
& $2 \mathrm{~kg}$ & 12.8 & 12.2 & 10.1 & $11.7 \mathrm{a}$ \\
\cline { 2 - 5 } $48 \mathrm{HST}$ & Rerata & $14.5 \mathrm{a}$ & $12.7 \mathrm{a}$ & $11.8 \mathrm{a}$ & $(-)$ \\
\hline & $1 \mathrm{~kg}$ & $40.6 \mathrm{a}$ & $25.9 \mathrm{bc}$ & $24.9 \mathrm{bc}$ & $30.5 \mathrm{a}$ \\
& $1,5 \mathrm{~kg}$ & $21.4 \mathrm{bc}$ & $27.4 \mathrm{bc}$ & $28.5 \mathrm{bc}$ & $25.7 \mathrm{a}$ \\
& $2 \mathrm{~kg}$ & $29.7 \mathrm{~b}$ & $28.2 \mathrm{bc}$ & $19.9 \mathrm{c}$ & $25.9 \mathrm{a}$ \\
\cline { 2 - 4 } Keterangan: & Rerata & $30.6 \mathrm{a}$ & $27.2 \mathrm{ab}$ & $24.4 \mathrm{~b}$ & $(+)$ \\
& Angka pada baris dan kolom yang diikuti dengan huruf yang sama tidak \\
& berbeda nyata menurut uji DMRT $\alpha$ 5\%. (-): Tidak terjadi interaksi antar
\end{tabular}

\subsection{Diameter Batang}

Hasil sidik ragam (Anova) menunjukkan bahwa terjadi interaksi antara takaran arang sekam padi dan frekuensi penyemprotan terhadap diameter batang 48 HST dimana batang tanaman yang diberikan arang sekam padi dengan takaran $1 \mathrm{~kg}$ per petak tanam kemudian disemprot dua kali paling besar.

Takaran arang sekam padi tidak berpengaruh nyata terhadap diameter batang 12 HST dan 30 HST dimana batang tanaman yang diberikan arang sekam padi pada semua takaran memberikan hasil paling besar.

Frekuensi penyemprotan tidak berpengaruh terhadap diameter batang pada setiap pengamatan tetapi data Tabel 5. Menunjukkan bahwa semua frekuensi penyemprotan pupuk organic cair yang diberikan pada tanaman memiliki diameter batang yang sama pada pengamatan 12 HST. Saat pengamatan $30 \mathrm{HST}$ dan 48 HST, frekuensi penyiraman tidak berpengaruh nyata terhadap diameter batang dimana batang tanaman yang disemprot satu kali memberikan hasil paling besar.

Tabel 5. Diameter Batang (cm)

\begin{tabular}{cccccc}
\hline Waktu & Takaran Arang & \multicolumn{2}{c}{ Frekuensi Penyemprotan POC } & \multirow{2}{*}{ Rerata } \\
\cline { 2 - 5 } Pengamatan & Sekam & 1 kali & 2 kali & 3 kali & \\
\hline \multirow{3}{*}{$12 \mathrm{HST}$} & $1 \mathrm{~kg}$ & 0.3 & 0.2 & 0.3 & $0.3 \mathrm{a}$ \\
& $1,5 \mathrm{~kg}$ & 0.3 & 0.3 & 0.3 & $0.3 \mathrm{a}$ \\
& $2 \mathrm{~kg}$ & 0.3 & 0.3 & 0.3 & $0.3 \mathrm{a}$ \\
\cline { 2 - 5 } & Rerata & $0.3 \mathrm{a}$ & $0.3 \mathrm{a}$ & $0.3 \mathrm{a}$ & $(-)$ \\
\hline \multirow{3}{*}{$30 \mathrm{HST}$} & $1 \mathrm{~kg}$ & 0.4 & 0.3 & 0.4 & $0.4 \mathrm{a}$ \\
& $1,5 \mathrm{~kg}$ & 0.4 & 0.4 & 0.4 & $0.4 \mathrm{a}$ \\
& $2 \mathrm{~kg}$ & 0.4 & 0.4 & 0.3 & $0.3 \mathrm{a}$ \\
\hline \multirow{3}{*}{$48 \mathrm{HST}$} & Rerata & $0.4 \mathrm{a}$ & $0.3 \mathrm{a}$ & $0.4 \mathrm{a}$ & $(-)$ \\
& $1 \mathrm{~kg}$ & $0.6 \mathrm{a}$ & $0.5 \mathrm{ab}$ & $0.5 \mathrm{ab}$ & $0.6 \mathrm{ab}$ \\
& $1,5 \mathrm{~kg}$ & $0.5 \mathrm{ab}$ & $0.6 \mathrm{a}$ & $0.7 \mathrm{a}$ & $0.6 \mathrm{a}$ \\
& $2 \mathrm{~kg}$ & $0.6 \mathrm{a}$ & $0.5 \mathrm{ab}$ & $0.4 \mathrm{~b}$ & $0.5 \mathrm{~b}$ \\
\hline & Rerata & $0.6 \mathrm{a}$ & $0.6 \mathrm{a}$ & $0.5 \mathrm{a}$ & $(+)$
\end{tabular}

Keterangan: Angka pada baris dan kolom yang diikuti dengan huruf yang sama tidak berbeda nyata menurut uji DMRT $\alpha 5 \%$. (-): Tidak terjadi interaksi antar faktor

\subsection{Panjang Buah per Tanaman}

Hasil sidik ragam (Anova) menunjukkan bahwa tidak terjadi interaksi antara takaran arang sekam padi dan frekuensi penyiraman terhadap panjang buah per tanama.

Takaran arang sekam padi berpengaruh nyata terhadap panjang buah per tanaman dimana buah dari tanaman yang diberikan arang sekam padi dengan takaran $1 \mathrm{~kg}$ per petak tanam paling panjang dan nyata berbeda dengan panjang buah dari tanaman yang diberikan arang sekam dengan takaran $2 \mathrm{~kg}$ per petak tanam.

Frekuensi penyiraman tidak berpengaruh nyata terhadap panjang buah pertanaman dimana buah dari tanaman yang semprot tiga kali paling panjang dibandingkan dengan frekuensi penyemprotan lainnya.

Tabel 6. Panjang Buah per Tanaman (cm)

\begin{tabular}{ccccc}
\hline Takaran & \multicolumn{3}{c}{ Frekuensi Penyemprotan POC } & \multirow{2}{*}{ Rerata } \\
\cline { 2 - 4 } Arang Sekam & 1 kali & 2 kali & $3 \mathrm{kali}$ & \\
\hline $1 \mathrm{~kg}$ & 15.4 & 16.4 & 16.3 & $16.0 \mathrm{a}$ \\
$1,5 \mathrm{~kg}$ & 15.0 & 16.2 & 15.0 & $15.4 \mathrm{a}$ \\
$2 \mathrm{~kg}$ & 9.7 & 12.4 & 16.0 & $12.7 \mathrm{~b}$ \\
\hline Rerata & $13.4 \mathrm{a}$ & $15.0 \mathrm{a}$ & $15.7 \mathrm{a}$ & $(-)$ \\
\hline Keterangan: & Angka pada baris dan kolom yang diikuti dengan huruf yang sama \\
& tidak berbeda nyata menurut uji DMRT $\alpha$ 5\%. (-): Tidak terjadi \\
& interaksi antar faktor
\end{tabular}




\subsection{Jumlah Buah Per Tanaman}

Hasil sidik ragam (Anova) menunjukkan bahwa tidak terjadi interaksi antara takaran arang sekam padi dan frekuensi penyiraman terhadap jumlah buah per tanaman. Takaran arang sekam padi tidak berpengaruh nyata terhadap jumlah buah per tanaman tetapi pada Tabel 7. menunjukan bahwa tanaman yang diberikan arang sekam padi dengan takaran $1 \mathrm{~kg}$ per petak tanam paling banyak dibandingkan dengan takaran arang sekam lainnya.

Frekuensi penyiraman juga tidak berpengaruh nyata terhadap jumlah buah per tanaman, Buah dari tanaman yang disemprot tiga kali paling banyak dari frekuensi penyemprotan lainnya.

Tabel 7. Jumlah Buah Per Tanaman

\begin{tabular}{ccccc}
\hline Takaran Arang & \multicolumn{3}{c}{ Frekuensi Penyemprotan POC } & \multirow{2}{*}{ Rerata } \\
\cline { 2 - 4 } Sekam & $1 \mathrm{kali}$ & $2 \mathrm{kali}$ & $3 \mathrm{kali}$ & \\
\hline $1 \mathrm{~kg}$ & 4.2 & 4.1 & 3.7 & $4.0 \mathrm{a}$ \\
$1,5 \mathrm{~kg}$ & 4.1 & 3.6 & 3.2 & $3.6 \mathrm{a}$ \\
$2 \mathrm{~kg}$ & 3.1 & 3.3 & 4.9 & $3.8 \mathrm{a}$ \\
\hline Rerata & $3.8 \mathrm{a}$ & $3.7 \mathrm{a}$ & $3.9 \mathrm{a}$ & $(-)$ \\
\hline Keterangan: & Angka pada baris dan kolom yang diikuti dengan huruf yang sama \\
& tidak berbeda nyata menurut uji DMRT $\alpha$ & $5 \%$. (-): Tidak terjadi \\
& interaksi antar faktor
\end{tabular}

\subsection{Berat Buah Per Tanaman}

Hasil sidik ragam (Anova) menunjukkan bahwa tidak terjadi interaksi antara takaran arang sekam padi dan frekuensi penyemprotan terhadap berat buah per tanaman. Takaran arang sekam padi tidak berpengaruh nyata terhadap berat buah per tanaman dimana buah dari tanaman yang diberikan arang sekam padi dengan takaran $1 \mathrm{~kg}$ per petak tanam paling berat dibandingkan dengan takaran arang sekam yang lain. Frekuensi penyiraman juga tidak berpengaruh nyata terhadap berat buah per tanaman tetapi data Tabel 8 . Menunjukan tanaman yang disemprotkan pupuk organic cair satu kali buahnya paling berat dari pada tanaman yang disemprotkan dua dan tiga kali.

Tabel 8. Berat Buah Per Tanaman (g)

\begin{tabular}{ccccc}
\hline Takaran Arang & \multicolumn{2}{c}{ Frekuensi Penyemprotan POC } & \multirow{2}{*}{ Rerata } \\
\cline { 2 - 4 } Sekam & 1 kali & 2 kali & $3 \mathrm{kali}$ & \\
\hline $1 \mathrm{~kg}$ & 20.0 & 20.2 & 21.3 & $20.5 \mathrm{a}$ \\
$1,5 \mathrm{~kg}$ & 25.2 & 19.8 & 16.2 & $20.4 \mathrm{a}$ \\
$2 \mathrm{~kg}$ & 16.8 & 15.6 & 23.2 & $18.5 \mathrm{a}$ \\
\hline Rerata & $20.7 \mathrm{a}$ & $18.5 \mathrm{a}$ & $20.2 \mathrm{a}$ & $(-)$ \\
\hline Keterangan: & Angka pada baris dan kolom yang diikuti dengan huruf yang sama \\
& tidak berbeda nyata menurut uji DMRT $\alpha$ 5\%. (-): Tidak terjadi \\
& interaksi antar faktor
\end{tabular}

\subsection{Berat Segar Berangkasan}

Hasil sidik ragam (Anova) menunjukkan tidak terjadi pengaruh interaksi antara takaran arang sekam padi dan frekuensi penyemprotan terhadap berat segar berangkasan. Cabe merah yang diberi arang sekam $2 \mathrm{~kg}$ lebih berat sedangkan tanaman cabe merah yang diberi arang sekam $1,5 \mathrm{~kg}$ memiliki berangkasan segar yang paling ringan. Data Tabel 9. menunjukkan bahwa cabe merah yang diberi arang sekam padi $2 \mathrm{~kg}$ dengan frekuensi penyemprotan $2 \mathrm{kali}$ memiliki berat segar berangkasan yang cenderung lebih berat dibandingkan dengan yang takaran dan frekuensi lainnya.

Tabel 9. Berat Segar Berangkasan (g)

\begin{tabular}{ccccc}
\hline Takaran Arang & \multicolumn{2}{c}{ Frekuensi Penyemprotan POC } & \multirow{2}{*}{ Rerata } \\
\cline { 2 - 4 } Sekam & 1 kali & 2 kali & $3 \mathrm{kali}$ & \\
\hline $1 \mathrm{~kg}$ & 48.4 & 45.7 & 46.2 & $46.8 \mathrm{a}$ \\
$1,5 \mathrm{~kg}$ & 45.6 & 47.3 & 44.5 & $45.8 \mathrm{a}$ \\
$2 \mathrm{~kg}$ & 45.8 & 56.7 & 41.9 & $48.1 \mathrm{a}$ \\
\hline Rerata & $46.6 \mathrm{a}$ & $49.9 \mathrm{a}$ & $44.2 \mathrm{a}$ & $(-)$ \\
\hline Keterangan: & Angka pada baris dan kolom yang diikuti dengan huruf yang sama \\
& tidak berbeda nyata menurut uji DMRT $\alpha$ 5\%. (-): Tidak terjadi \\
& interaksi antar faktor
\end{tabular}

\subsection{Berat Kering Berangkasan}

Hasil sidik ragam (Anova) menunjukkan bahwa tidak terjadi interaksi antara takaran arang sekam padi dan frekuensi penyiraman terhadap berat kering berangkasan. Tanaman yang diberikan arang sekam padi dengan takaran $2 \mathrm{~kg}$ per petak tanam yang disemprotkan dua kali paling berat yang tidak berbeda nyata dengan berat kering berangkasan tanaman yang diberikan arang sekam padi dengan takaran $1 \mathrm{~kg}$ dan $1,5 \mathrm{~kg}$ per petak tanam kemudian disemprotkan dua kali.

Tabel 10. Berat Kering Berangkasan (g)

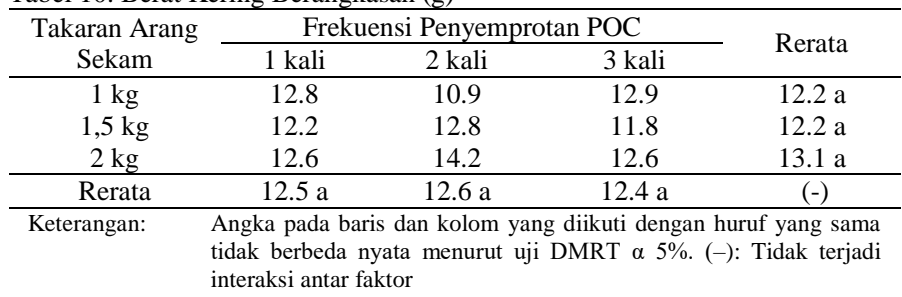

Frekuensi penyiraman juga tidak berpengaruh nyata terhadap berat kering berangkasan tetapi Tabel 10. menunjukan bahwa frekuensi penyemprotan dua kali memiliki brangkasan kering yang lebih berat dari tanaman yang disemprotkan satu kali dan tiga kali.

\subsection{Indeks Panen}

Hasil sidik ragam (Anova) menunjukkan bahwa tidak terjadi interaksi antara takaran arang sekam padi dan frekuensi penyemprotan terhadap indeks panen. Takaran arang sekam padi juga tidak berpengaruh nyata terhadap indeks panen tetapi data Tabel 11. menunjukkan bahwa indeks panen dari tanaman yang diberikan arang sekam padi $1,5 \mathrm{~kg}$ per petak tanam cenderung lebih tinggi sedangkan indeks panen dari tanaman yang diberikan arang sekam padi dengan takaran $2 \mathrm{~kg}$ per petak tanam paling rendah.

Tabel 11. Indeks Panen (\%)

\begin{tabular}{ccccc}
\hline Takaran Arang & \multicolumn{2}{c}{ Frekuensi Penyemprotan POC } & \multirow{2}{*}{ Rerata } \\
\cline { 2 - 4 } Sekam & $1 \mathrm{kali}$ & $2 \mathrm{kali}$ & $3 \mathrm{kali}$ & \\
\hline $1 \mathrm{~kg}$ & 28.9 & 29.2 & 29.5 & $29.2 \mathrm{a}$ \\
$1,5 \mathrm{~kg}$ & 36.0 & 29.9 & 26.4 & $30.8 \mathrm{a}$ \\
$2 \mathrm{~kg}$ & 26.4 & 22.2 & 36.5 & $28.4 \mathrm{a}$ \\
\hline Rerata & $30.4 \mathrm{a}$ & $27.1 \mathrm{a}$ & $30.8 \mathrm{a}$ & $(-)$ \\
\hline Keterangan: & Angka pada baris dan kolom yang diikuti dengan huruf yang sama \\
& tidak berbeda nyata menurut uji DMRT $\alpha$ 5\%. (-): Tidak terjadi \\
& interaksi antar faktor
\end{tabular}

Frekuensi penyemprotan tidak berpengaruh nyata terhadap indeks panen, tetapi tanaman cabe merah yang disemprotkan pupuk organic cair 3 kali memiliki nilai indeks panen paling tinggi. Sedangkan tanaman cabe merah yang disemprotkan dua kali memiliki nilai indeks panen paling rendah.

\subsection{Pembahasan}

Pemberian arang sekam padi dengan takaran $2 \mathrm{~kg}$ per petak memberikan hasil panen berupa berat segar brangkasan dan berat kering brangkasan yang paling berat walaupun pertumbuhan vegetatif berupa tanaman yang lebih pendek dan diameter batang yang kecil tetapi tidak berbeda nyata dengan takaran arang sekam padi $1 \mathrm{~kg}$ per petak tanam.

Frekuensi penyemprotan tiga kali memberikan pertumbuhan vegetatif tanaman berupa tinggi dan diameter batang yang tidak berbeda nyata sehingga buah yang dihasilkan berukuran paling panjang dengan jumlah buah pada setiap tanaman yang paling banyak, walaupun buah yang dihasilkan setiap tanaman tidak berat tetapi tidak berbeda nyata dengan takaran arang sekam padi $1 \mathrm{~kg}$ per petak tanam tetapi nilai indeks panen yang tertinggi yaitu $30,8 \%$.

Penelitian ini dapat menghasilkan hasil yang baik, namun terjadinya keguguran buah yang sangat banyak dan terdapat penyakit busuk buah yang di akibatkan oleh air hujan yang berlebihan. Penyakit busuk buah yang hingga saat ini sangat ditakuti oleh petani cabai adalah penyakit Antraknosa (patek). Penyebab penyakit ini adalah cendawan Colletotrichum capsici dan Gloesporium piperatum. Gejala awal dari penyakit ini adalah bercak coklat kehitaman pada buah, sedikit terbenam dan berair yang kemudian meluas menjadi busuk lunak. Serangan berat menyebabkan buah mengering dan keriput seperti jerami akibat infeksi. Gloesporium piperatum menyerang tanaman cabai mulai pada saat buah masih berwarna hijau dan menyebabkan die back (mati ujung). Pada kondisi lembab, cendawan membentuk badan buah dalam lingkaran- lingkaran memusat berwarna merah jambu (Prajnanta, 2011).

\section{Simpulan}

Interaksi antara takaran arang sekam padi dan frekuensi penyemprotan terjadi pada kadar lengas 30 HST, tinggi tanaman 48 HST dan diameter batang 48 HST. Takaran arang sekam padi berpengaruh nyata terhadap suhu tanah 30 HST dan 48 HST, kadar lengas tanah 30 HST, diameter batang 48, dan panjang buah per tanaman. Sedangkan frekuensi penyiraman berpengaruh nyata terhadap kadar lengas 48 HST dan tinggi tanaman 48 HST. Takaran arang sekam padi 2 $\mathrm{kg}$ per petak tanam menghasilkan berangkasan segar dan berangkasan kering yang paling berat. Frekuensi penyemprotan dua kali memberikan memiliki berat segar berangkasan yang cenderung lebih berat dibandingkan dengan yang takaran dan frekuensi lainnya. Takaran arang sekam padi $1 \mathrm{~kg}$ per petak tanam memberikan hasil panen tertinggi $0,05 \mathrm{t} /$ ha sedangkan frekuensi penyemprotan 3 kali memberikan hasil panen tertinggi 0,5 t/ha

\section{Pustaka}

Ayub S., Pranata, 2004. Pupuk Organik Cair, Aplikasi dan Manfaatnya. Agro Media Pustaka. Depok.

BPS TTU,2010. Survei Pertanian Produksi Tanaman Sayur - Sayuran dan Buah -Buahan. Kabupaten TTU Kefamenanu.

Darmayati, 2003.Khasiat dan Manfaat Obat -Obatan. Agromedia Pustaka,Jakarta.

Gomez, K. A. dan A. A. Gomes. 1995. Prosedur Statistik untuk Penelitian Pertanian. Edisi ke 2. Jakarta:UI Press.

Rukmana R., 1994, Bertanam Bayam. Penerbit Kanisius, Yogyakarta.

Sunaryono, 1981. Pengantar Pengetahuan Dasar Hortikultura.Sinar Baru. Bandung 